We have provisionally placed the proteins studied by us in the following classification :

Class I. Crystalline methæmoglobin (prep. Dr. Danielli). Crystalline insulin (commercial for physiological use).

Class III. Crystalline ovo-albumen (prep. Dr. Danielli ; many times recrystallized).

Myosin (prep. Dr. Bate-Smith. Preparations made in Cambridge, unlike those of Edsall et al. ${ }^{1}$, show little or no flow birefringence, but appear in all other ways undenatured).

Pseudoglobulin from amphibian neurulæ.

Aged tobacco-mosaic virus nucleoprotein (which showed less than one-tenth of its original intensity of flow birefringence).

Class II. Tobacco-mosaic virus nucleoprotein (prep. Dr. Pirie. Here our results are in complete confirmation of those of Robinson ${ }^{2}$ ).

Total globulin fraction from amphibian neurulæ.

"Myosin" fraction from amphibian neurulæ.

To the above we should like only to add that we have noted remarkable continuous decreases in relative viscosity of certain protein solutions even when standing at $0^{\circ} \mathrm{C}$., notably the amphibian embryo pseudoglobulin fraction. In most of the proteins studied the concentration/viscosity relationship must have the characteristic curves sharply bent between the steep and flat regions, since it is often difficult to hit upon the concentration which will give a relative viscosity in the optimal region for observation.
As regards the embryological significance of our findings, it may be said that they strengthen previous indications (such as those of Miller and Moore $^{3}$, Schmidt4, Needham and Robinson ${ }^{5}$, etc.) of the existence of anisometric particles in developing eggs and embryos. Such particles may well be concerned with the shape changes of neural cell formation. The proteins were extracted from embryos frozen at $-77^{\circ} \mathrm{C}$. and dried in vacuo by methods similar to those of Mirsky ${ }^{6}$. Apart from the behaviour of pseudoglobulin, the anomalous flow of the globulin fraction (consisting largely but not entirely of vitellin) invites the question whether vitellin has not been looked upon in the past too exclusively as a nutritive reserve. Yolk-platelets of amphibia were stated long ago by Radlkofer ${ }^{7}$ to show weak birefringence. We hope in due course to publish a complete account of the foregoing experiments and to continue the examination of the viscosity of protein solutions both from embryonic and other sources, on which so much remains to be done.

\footnotetext{
1 Edsall and Mehl, J. Biol. Chem., 133, 409 (1940).

${ }^{2}$ Robinson, Proc. Roy. Soc., A, 170, 519 (1939).

${ }^{3}$ Miller and Moore, Proc. Soc. Exp. Biol. and Med., 36, 835 (1937).

${ }^{4}$ Schmidt., Ber. Ges. Nat. u. Heilkunde, Giessen, 17, 140 (1936).

5 Needham and Robinson, C.R. Soc. Biol., 126, 163 (1937).

${ }^{6}$ Mirsky, Science, 84, 333 (1936).

${ }^{2}$ Radlkofer, "Uै. Krystalle proteinartiger Körper pflanzlichen u. thierischen Ursprungs", Leipzig (1859).
}

\title{
MARINE ECOLOGY AT HULL
}

$I^{N}$ VESTIGATIONS on the ecology of plankton in the North Sea and the relationships between the plankton and the fisheries have been made now for some years at the Department of Zoology and Oceanography at University College, Hull, under the direction of Prof. A. C. Hardy. The results of some of this work have been published elsewhere, but recently Prof. Hardy has started a new periodical for oceanographical investigations undertaken by the Department. This is entitled the Hull Bulletins of Marine Ecology, of which Nos. 1 and 2 of vol. 1 appeared in November 1939 and vol. 1, No. 3 in March 1940. The publications to date are concerned with research with the continuous plankton recorder. No. 1, which is by Prof. Hardy, contains an account of the ingenious recording machine and the method of working it, together with a summary of the plan and scope of the survey made with the instrument. A number of collecting lines have been run across the North Sea at regular intervals of time, and No. 2 of the Hull Bulletins contains a list of records made from 1932 until 1937.

The idea of the survey is to attempt "to apply methods similar to those employed in meteorology to a study of the changing plankton distribution, its causes and effects". In this respect it has considerable bearing on problems of the economic fisheries, such as the influence of the amount of plankton in any one area and at any one time on the survival of young fish and the movements of shoals of adults. At the same time the collections provide an index of the movements of water masses as indicated by the contained plankton organisms. No. 3, by C. E. Lucas, contains an account of the distribution of the phytoplankton in the southern North Sea in 1932-37 as shown by the continuous recorder. The report is chiefly in the form of data on which comparisons of different years may be based, and interesting differences are already apparent. Any full consideration of the results must, however, naturally await the final working up and correlation of all the material available.

The scheme of research undertaken by Prof. Hardy was ambitious, and he will earn the gratitude of oceanographers for having carried it through with such signal success. The results already published show good prospects that, given the funds and opportunity, the continuous observation of certain aspects of oceanography on meteorological lines is a possibility.

It is most regrettable that the War has brought these observations temporarily to a close, and when times of peace return they should be restarted and extended over even wider areas. The Hull Bulletins of Marine Ecology will form an important addition to oceanographical literature; it would be most unfortunate if, as suggested on their cover, they only formed a completed work of one or two volumes. In welcoming the new serial the hope may, therefore, be expressed that in due course it will become a permanent addition to publications devoted to oceanographical research, for in Great Britain the number of such journals is at present far from adequate. 